IJOTL TL, Vol. 4, No. 3, September 2019

p ISSN: 2502 2326; e ISSN: 2502 8278

Https://soloclcs.org; Email: ijolt1@gmail.com

Center of Language and Cultural Studies, Surakarta, Indonesia

Rahman, Dzul; Sunarti \& Arbain. 2019. The Effect of E-learning Based Schoology

on the Learning Outcomes in Nursing Program.

IJOTL TL (2019), 4(3): 163 172. DOI: 10.30957/ijotl-tl.v4i3.607.

\title{
The Effect of E-learning Based Schoology on the Learning Outcomes in Nursing Program
}

\author{
Dzul Rachman, Sunarti \& Arbain \\ Universitas Muhammadiyah Kalimantan Timur \\ dr650@umkt.ac.id \\ sun377@umkt.ac.id
}

\section{Universitas Widya Gama Mahakam Samarinda baintigers@gmail.com}

\begin{abstract}
The fast advance of information technology has attempted English teachers with innovative and recent teaching models. This study focuses on the use of Schoology in ESP nursing class. The quantitative research was done with one group pre-test and post-test design. The samples were the second semester ESP class of Nursing program as an experimental group that consists of 122 students and 122 students as a control group. The instruments used the test to measure the students' cognitive achievement. The inferential analysis used in this research was a t-test. Based on the results of Group Statistics, it is found that the average value of the posttest for the control group was 61.05 while the experimental group was 84 . Thus, statistically, it can be concluded that there are significant differences in learning outcomes between the control group with the lecture method and the experimental group using Schoology. In other words, the use of Schoology is effective in learning also helps improve English learning outcomes of students of Nursing Program.
\end{abstract}

Keywords: E-Learning, Learning Management System (LMS), Schoology, Nursing program

\section{INTRODUCTION}

Children or youth to experience have a heavy dependence on information. The need for machinery and knowledge is highly diverse, one simple step to approach material is with social media. Many sets of social devices that arise now faces many societies to become users. The premise that social media can produce dependency on its users, it looks to have become a negative attitude in the study of social media today. Experts figure out that they tend an individual to the internet owing to stress held by people (Young, 2011). An individual with such a view will use social media as a way of reducing the sense of desolation and, instead of direct communication, not getting into normal life. capable of being a conduit for someone who has passive actions while reaching out to be able to tell words to others. Users often have clarity in their selfidentity and how they interpret or build up themselves in the virtual life (Nasrullah, 2015:30). 
IJOTL TL, Vol. 4, No. 3, September 2019

p ISSN: 2502 2326; e ISSN: 2502 8278

Https://soloclcs.org; Email: ijolt1@gmail.com

Center of Language and Cultural Studies, Surakarta, Indonesia

Rahman, Dzul; Sunarti \& Arbain. 2019. The Effect of E-learning Based Schoology

on the Learning Outcomes in Nursing Program.

IJOTL TL (2019), 4(3): 163 172. DOI: 10.30957/ijotl-tl.v4i3.607.

This can mean that an individual will have his personality has been expressed through a written information. In addition, the excitement of conversation can be looked at from comments, status or chat on social media accounts they have such as twitter, BBM, whatsaap, instagram, facebook and so forth, so typically for those who have indifferent behavior feel more convenient in the process of conversation through social media which can establish dependence on social media.

According to online media news reports (Taylor, 2013), Japan's Ministry of Education concludes that 518,000 youths in Japan aged 12 and 18 were obsessed to social media by 2013 , and they require to be recovered. The Japanese state is dealt with that the issue of this reality may be limited. The efficiency with which information technology relies on its purchasers. Dependency is the undertaking to reach the desires or complete the objectives by relying on alternative media, in this instance social forms (Schrock, 2006; Sucipto, Efendi, Hanif \& Budiyanto, 2017). The particular way to meet the need for information and knowledge is through social channels.

E-Learning is a technology that has made a major contribution to the improvement of the learning process. Students not only listen to contextual explanations from educators, but also participate in $5 \mathrm{M}$ activities (watching, questioning, collecting, associating, and communicating). The e-learning system used by schools is generally limited to students who submit the assignment and cannot know the input from the project. E-Learning method used by schools is generally limited to students sending the task and cannot know the feedback from the task. Communication between students and teachers is limited to the process of learning in the classroom. In addition, students often have difficulty obtaining teaching materials or materials that have been described by the teacher. Utilization of technology in the learning process becomes one of the solutions to overcome these problems. It is different from the traditional learning process which relies on lecturers as the first and main learning source while other sources are only a complement to learning activities. The rapid development of technology, especially communication technology has brought big changes in various fields. One area that has also developed as a result of advances in communication technology is education and learning. If in the previous time, the relationship between student educators only took place through face-to-face activities, limited by space and time barriers, or through print media, it turns out that now it has been developed through online communication which is not limited by space and time barriers. If we look at the process of learning English, in a nursing study program, it involves more than 50 students in a class where the discussion includes four skills such as speaking, reading, listening and writing. Looking at the target to understand the material is very hard to achieve, it is necessary to have a suitable learning approach as a benchmark for students to understand the material that has been delivered.

There are numerous forms of information and conversation technology applicable in the community that are ready to be applied better optimally for academic purposes. One of them is a reciprocal learning tools based on e-learning, Schoology. Schoology is one of the web-based social web pages which presents the same free and simple-to-use classroom learning as Facebook (Aminoto \& Pathoni, 2014). From the above summary, the scientists wished to investigate to get out, through an 
IJOTL TL, Vol. 4, No. 3, September 2019

p ISSN: 2502 2326; e ISSN: 2502 8278

Https://soloclcs.org; Email: ijolt1@gmail.com

Center of Language and Cultural Studies, Surakarta, Indonesia

Rahman, Dzul; Sunarti \& Arbain. 2019. The Effect of E-learning Based Schoology

on the Learning Outcomes in Nursing Program.

IJOTL TL (2019), 4(3): 163 172. DOI: 10.30957/ijotl-tl.v4i3.607.

understanding management system (LMS)-based learning program such as Schoology, if this approach is a powerful and useful way to accomplish fixed academic objectives and can support undergraduates to totally grasp all the elements they require to comprehend.

The expeditious expansion of IT involves given different teaching styles to English educators. As a following, engineering shows a particularly significant part in developing English. According to Stošić (2015), undergraduates can individually master substances by applying academic technology, determine the learning speed, repetition substances that are not adequately precise, and record their development in understanding. One of technologies employed in English language teaching and learning is Learning Management System (LMS).

LMSs are web-based programs created for administration, documentation, monitoring, informing, and distribution of courses in both higher school and new academic schemes. They can facilitate in regular classrooms, distance studying, or any combination of the two. LMSs distribute and use didactic content and generally deal with pupil enrollment, online course management, and record and judgment of undergraduate performance (Ghilay, 2017). LMSs are identified by different calls: course management system (CMS), learning content management system (LCMS), virtual learning environment (VLE), and virtual learning system (VLS) (Wright, Lopes, Montgomerie, Reju \& Schmoller, 2014). Higher education institutes benefit from adopting an LMS in the coming ways: (a) tutor and graduate access to learning subject matter anytime and anywhere, (b) an integrated authority of understanding, (c) record and documenting devices to increase undergraduate understanding and achievement, (d) extended productivity in undergraduate projects such as homework submission, (e) enhanced information, and (f) understanding analytics. Despite a successful acceptance and adoption of an LMS in higher education, clients such as academic directors, department, and graduates support LMS merchants to develop LMS elements and operates (Brown, Dehoney \& Millichap, 2015; Dahlstrom, Brooks \& Bichsel, 2014).

Research on the use of social net-based LMS have been managed highly in Indonesia. First, Mulyono (2016) investigated the adoption of Quipper as a wire program for instruction and studying English as a foreign language (EFL) in SMA Negeri 92 Jakarta. The author concentrated on the extent to which features applicable in Quipper may coincide to the principal factors of Computer-Assisted Language Learning (CALL) pedagogy. The results proved that Quipper was economical for being accepted as an online learning and learning EFL platform. Quipper corresponded to the three conditions of CALL pedagogy. Thus, it is a possible aid for activities employed in teaching and learning EFL, i.e. L2- input exposure, communication, and grammatical construction. Second, Ardi (2017) examines Schoology m-learning program adopted in an English for Academic Purposes (EAP) Class. The investigator described how Schoology m-learning platform facilitated the handling of learner autonomy in an EAP class. The investigator noticed that Schoology m-learning platform installed in mobile devices served the students with stronger authority over their EAP learning beyond the classroom, both in calls of the process and substance of their learning. Third, Purnawarman, Susilawati, and Sundayana (2016) used Edmodo to instruct English for 
IJOTL TL, Vol. 4, No. 3, September 2019

p ISSN: 2502 2326; e ISSN: 2502 8278

Https://soloclcs.org; Email: ijolt1@,gmail.com

Center of Language and Cultural Studies, Surakarta, Indonesia

Rahman, Dzul; Sunarti \& Arbain. 2019. The Effect of E-learning Based Schoology

on the Learning Outcomes in Nursing Program.

IJOTL TL (2019), 4(3): 163 172. DOI: 10.30957/ijotl-tl.v4i3.607.

the eleventh grade students. The researchers examined how Edmodo was carried out in teaching writing. The analysts identified that Edmodo facilitated students' engagement cognitively through Note menu. The scholars showed varied responses both constructive and negative towards the adoption of Edmodo.

In the past investigations, the analysts analyzed the viability of the utilization of LMS and their examinations are proposed for senior secondary school understudies and college understudies. Roused by the past investigations, the scientist means to additionally look at the impacts of Schoology to spur middle school understudies to learn English. Stockwell (2013) contends that innovation make English educators and students simpler to get to a wide scope of English assets around the globe.

Technologies have advantage of communicating with others both all through the classroom. It was connected to persuasive increments through interfacing with a genuine crowd. Besides, Stockwell (2013) satisfies that language learning framework that keeps tabs on understudies' development and gives input empowers the understudies to perceive what they have realized and what despite everything they must ponder. It can support understudies' inspiration and continue their endeavors in considering the language. This present examination centers around the utilization of Schoology in ESP nursing class. Steinberg and Riehl (2013) contend that "Schoology is an informal organization-based Learning Management System (LMS) that makes making and sharing scholastic substance simple". Schoology gives some fascinating highlights that can propel understudies. The highlights help understudies in learning process effectively, so understudies make the most of their learning.

\section{METHODS}

Quantitative research was done with one group pre-test and post-test design. Taken purposively, a class of the second semester at Health and Pharmacy faculty, Universitas Muhammadiyah Kalimantan Timur, majoring in Nursing that consists of two hundred forty four students was the sample of this research. The samples were the second semester ESP class as an experimental group that consists of 122 students and 122 students as a control group. There are two variables in the overall of this analysis:

1) Dependent Variable. The dependent variable of this research is scholars' English performance. 2) Independent Variable. Schoology in Blended Learning is the assisted variable of this research, independent variable.

The instruments used were the test which the test function to measure the students' cognitive achievement. The valid instruments were subsequently tested before being used in research to determine the level of reliability. Based on statistical analysis calculations by the Cronbach alpha formula, the obtained value of the degree of cognitive achievement test $=0.780$. Data were analyzed using descriptive and inferential analysis. The inferential analysis used in this research was a t-test. T-test term refers to the test of normality and homogeneity of data. This test aims to determine whether there is a difference is generated between the control group and the experimental group.

\section{RESULTS}


IJOTL TL, Vol. 4, No. 3, September 2019

p ISSN: 2502 2326; e ISSN: 2502 8278

Https://soloclcs.org; Email: ijolt1@,gmail.com

Center of Language and Cultural Studies, Surakarta, Indonesia

Rahman, Dzul; Sunarti \& Arbain. 2019. The Effect of E learning Based Schoology

on the Learning Outcomes in Nursing Program.

IJOTL TL (2019), 4(3): 163 172. DOI: 10.30957/ijotl-tl.v4i3.607.

Based on the calculation results of the N-Gain Score test, the table shows that the average value of the N-Gain Score in the Experiment group that uses Schoology in the lecture process is $56.6516 \%$ or $57 \%$ which refers to the interpretation of the effectiveness of the N-Gain into the category Quite Effective with a minimum M-Gain value of $27.3 \%$ and a maximum value of $80 \%$. As for the control group, the average is $7.6959 \%$ or $7.7 \%$, which means the use of lecture methods in class is categorized as Ineffective category. Thus, it can be concluded that the use of Schoology is quite effective in learning English for students of nursing study programs which can be seen in the significant success of learning outcomes while lecture method is ineffective. This was also supported by the results of the t-test from both groups.

\begin{tabular}{|c|c|c|c|c|c|}
\hline & \multicolumn{3}{|c|}{ Group } & Statistic & Std. Error \\
\hline \multirow[t]{18}{*}{ NGain_Percent } & \multirow[t]{13}{*}{ control } & \multicolumn{2}{|l|}{ Mean } & 7.6959 & 0.85822 \\
\hline & & \multirow[t]{2}{*}{$\begin{array}{l}\text { 95\% Confidence Interval for } \\
\text { Mean }\end{array}$} & $\begin{array}{l}\text { Lower } \\
\text { Bound }\end{array}$ & 5.9968 & \\
\hline & & & $\begin{array}{l}\text { Upper } \\
\text { Bound }\end{array}$ & 9.395 & \\
\hline & & \multicolumn{2}{|l|}{$5 \%$ Trimmed Mean } & 6.7638 & \\
\hline & & \multicolumn{2}{|l|}{ Median } & 5.3 & \\
\hline & & \multicolumn{2}{|l|}{ Variance } & 89.859 & \\
\hline & & \multicolumn{2}{|l|}{ Std. Deviation } & 9.47938 & \\
\hline & & \multicolumn{2}{|l|}{ Minimum } & 0 & \\
\hline & & \multicolumn{2}{|l|}{ Maximum } & 38.1 & \\
\hline & & \multicolumn{2}{|l|}{ Range } & 38.1 & \\
\hline & & \multicolumn{2}{|l|}{ Interquartile Range } & 11.58 & \\
\hline & & \multicolumn{2}{|l|}{ Skewness } & 1.232 & 0.219 \\
\hline & & \multicolumn{2}{|l|}{ Kurtosis } & 0.796 & 0.435 \\
\hline & \multirow[t]{5}{*}{ experiment } & \multicolumn{2}{|l|}{ Mean } & 56.6516 & 0.92433 \\
\hline & & \multirow[t]{2}{*}{$\begin{array}{l}95 \% \text { Confidence Interval for } \\
\text { Mean }\end{array}$} & $\begin{array}{l}\text { Lower } \\
\text { Bound }\end{array}$ & 54.8217 & \\
\hline & & & $\begin{array}{l}\text { Upper } \\
\text { Bound }\end{array}$ & 58.4816 & \\
\hline & & \multicolumn{2}{|l|}{$5 \%$ Trimmed Mean } & 56.7324 & \\
\hline & & \multicolumn{2}{|l|}{ Median } & 57.1 & \\
\hline
\end{tabular}


IJOTL TL, Vol. 4, No. 3, September 2019

p ISSN: 2502 2326; e ISSN: 2502 8278

Https://soloclcs.org; Email: ijolt1@gmail.com

Center of Language and Cultural Studies, Surakarta, Indonesia

Rahman, Dzul; Sunarti \& Arbain. 2019. The Effect of E learning Based Schoology

on the Learning Outcomes in Nursing Program.

IJOTL TL (2019), 4(3): 163 172. DOI: 10.30957/ijotl-tl.v4i3.607.

\begin{tabular}{l|l|l|l|l}
\hline \multirow{n}{*}{} & Variance & 104.234 & \\
\cline { 3 - 5 } & Std. Deviation & 10.2095 & \\
\cline { 3 - 5 } & Minimum & 27.3 & \\
\cline { 3 - 5 } & Maximum & 80 & \\
\cline { 3 - 5 } & Range & 52.7 & \\
\cline { 3 - 5 } & Interquartile Range & 13.6 & \\
\cline { 3 - 5 } & Skewness & -0.168 & 0.219 \\
\cline { 3 - 5 } & Kurtosis & -0.04 & 0.435 \\
\hline
\end{tabular}

Based on the results of Group Statistics, it is found that the average value of the posttest for the control group was 61.05 while the experimental group was 84 . Thus, statistically, it can be concluded that there are significant differences in learning outcomes between the control group with the lecture method and the experimental group using Schoology. In other words, the use of Schoology is effective in learning also helps improve English learning outcomes of students of Nursing Program in UMKT.

\begin{tabular}{l|l|l|l|l|l}
\hline \multicolumn{6}{l}{ Group Statistics } \\
\hline & Group & N & Mean & Std. Deviation & Std. Error Mean \\
\hline \multirow{2}{*}{ Post-test } & control & 122 & 61.05 & 9.27 & 0.839 \\
\cline { 2 - 7 } & experiment & 122 & 84 & 3.839 & 0.348 \\
\hline
\end{tabular}

Based on the following table, the Sig. (2-tailed) of $0.001<0.05$, it is concluded that there were differences in achievement of English learning outcomes in the control and experiment groups which meant that students of Nursing study program of UMKT in the experimental group, that has used Schoology to support the learning activities, have obtained better learning outcomes with improvement on their grades which is significant compared to the control group that still used the lecture method. 
IJOTL TL, Vol. 4, No. 3, September 2019

p ISSN: 2502 2326; e ISSN: 2502 8278

Https://soloclcs.org; Email: ijolt1@gmail.com

Center of Language and Cultural Studies, Surakarta, Indonesia

Rahman, Dzul; Sunarti \& Arbain. 2019. The Effect of E-learning Based Schoology

on the Learning Outcomes in Nursing Program.

IJOTL TL (2019), 4(3): 163 172. DOI: 10.30957/ijotl-tl.v4i3.607.

\begin{tabular}{|c|c|c|c|c|c|c|c|c|c|c|}
\hline \multicolumn{11}{|c|}{ Independent Samples Test } \\
\hline & & \multicolumn{2}{|c|}{$\begin{array}{l}\text { Levene's Test } \\
\text { for Equality } \\
\text { of Variances }\end{array}$} & \multicolumn{7}{|c|}{ t-test for Equality of Means } \\
\hline & & \multirow[t]{2}{*}{$\mathbf{F}$} & \multirow[t]{2}{*}{$\begin{array}{l}\text { Si } \\
\text { g. }\end{array}$} & \multirow[t]{2}{*}{$\mathbf{t}$} & \multirow[t]{2}{*}{ df } & \multirow[t]{2}{*}{$\begin{array}{l}\text { Sig. (2- } \\
\text { tailed) }\end{array}$} & \multirow[t]{2}{*}{$\begin{array}{l}\text { Mean } \\
\text { Difference }\end{array}$} & \multirow[t]{2}{*}{$\begin{array}{l}\text { Std. Error } \\
\text { Difference }\end{array}$} & \multicolumn{2}{|c|}{$\begin{array}{l}95 \% \\
\text { Confidence } \\
\text { Interval of the } \\
\text { Difference } \\
\end{array}$} \\
\hline & & & & & & & & & Lower & Upper \\
\hline \multirow[b]{2}{*}{ Postest } & $\begin{array}{l}\text { Equal } \\
\text { variances } \\
\text { assumed }\end{array}$ & 56.498 & $\begin{array}{l}0,0 \\
01\end{array}$ & $\overline{25.265}$ & 242 & 0.001 & -22.951 & 0.908 & $\begin{array}{l}- \\
24.740\end{array}$ & $\begin{array}{l}- \\
21.161\end{array}$ \\
\hline & $\begin{array}{l}\text { Equal } \\
\text { variances } \\
\text { not } \\
\text { assumed } \\
\end{array}$ & & & $\begin{array}{l}- \\
25.265\end{array}$ & $\begin{array}{l}161 \\
.31 \\
7\end{array}$ & 0.001 & -22.951 & 0.908 & $\begin{array}{l}- \\
24.745\end{array}$ & $\begin{array}{l}- \\
21.157\end{array}$ \\
\hline
\end{tabular}

\section{DISCUSSION AND CONCLUSION}

Cognitive achievement tests were performed twice: before learning (pre-test) and after learning (post-test). Based on the result of the homogeneity test, pre-test results of students in the experimental class and control indicate as homogeneous. Also, based on the results of inferential analysis using t-test on the pre-test, the students in both classes have no significant differences in cognitive achievements between experimental and control class. Based on the test result of inferential analysis using a ttest, there is a significant difference in the result between the two classes after being given the treatment. The difference is due to the learning achievement of the experimental class and class control using Schoology.

Comparison of improvement of students' cognitive learning achievements in the experimental class and control one can be known by determining the value of $\mathrm{N}$-gain in both classes of the pre-test and post-test for each class. The research showed the average value of the two classes of N-gain, then they are compared to determine which class whose cognitive learning achievement is better. The average of $\mathrm{N}$-gain of the experimental class is 0.77 , and it is included in the high category, while the average of $\mathrm{N}$-gain of the control class is 0.66 and it is included in the medium category.

The result of this study is in line with the previous study which stated that the learning model with web-assisted could improve learning outcomes and student perceptions. The findings obtained are because students who use these learning can reduce the risk of memory loss and can increase the value of the examination. Also, the other study shows an increase in learning outcomes of students by using Schoology. Attitude achievement is the impact of the accompaniment of the results of a learning process as a result of the creation of a learning atmosphere experienced by students. Students' curiosity and responsibility increase significantly before and after learning. The attitude of students has developed in a good category so that more steady habituation of the internalization of aspects of attitude requires a longer and more continuous time. 
IJOTL TL, Vol. 4, No. 3, September 2019

p ISSN: 2502 2326; e ISSN: 2502 8278

Https://soloclcs.org; Email: ijolt1@,gmail.com

Center of Language and Cultural Studies, Surakarta, Indonesia

Rahman, Dzul; Sunarti \& Arbain. 2019. The Effect of E-learning Based Schoology

on the Learning Outcomes in Nursing Program.

IJOTL TL (2019), 4(3): 163 172. DOI: 10.30957/ijotl-tl.v4i3.607.

Based on the results and discussion of the study, it is concluded that there is a significant difference in cognitive learning outcomes between the students who learn the material of solubility and constant solubility product using Schoology in the learning activities. The results show that although both educational strategies have proved effective when acquiring new knowledge, the improvement in the results obtained in the post-test of the subjects who used the tool Schoology are significantly higher compared to those who did not use it, all without incurring an increase in activities with regard to control groups, which comes to support the studies of. In addition to this, different from other articles Pilli (2014) in his study on the use of Schoology to improve academic performance in students from teaching degree in Peru, indicating that there were no significant differences regards to the results by using the Schoology tool. The study concludes that the improvement with the use of this tool "LMS" was significant both in the experimental group of TTES and in the CAFD, being even higher in the groups with an increase of 3.32 points $(-1.34)$ between the pre and post-test, compared to the 0.89 points $(-1.87)$ of the control group. It is also concluded from these results that the adaptation of the students to the use of Schoology has been fast and efficient which can fit in within the conclusions of Stošić (2015) who indicates that using the social networks like virtual tools for generating learning is something that has been carried out mainly in the field of university education, because this type of students already show some mastery in the management of these tools and therefore, there is no need for so much learning time.

\section{REFERENCES}

A. Tugiyo, P. Hairul, and T. Aminoto, (2014) "Penerapan Media E-Learning Berbasis Schoology untuk Meningkatkan Aktivitas dan Hasil Belajar Materi Usaha dan Energi di Kelas XI SMA N 10 Kota Jambi". J Sainmatika. vol. 8, no.1, pp. 1629.

Ardi, P. (2017). Promoting learner autonomy through Schoology m-learning platform in an EAP class at an Indonesian University. The Journal of Teaching English with Technology, 17(2), 55-76.

Ayub, A. F. M., Tarmizi, R. A., Jaafar, W. M. W., Ali, W. Z. W., \& Luan, W. S. (2010). Factors influencing students' use a learning management system portal: Perspective from higher education students. International Journal of Education and Information Technologies, 4(2), 100-108.

Brown, M., Dehoney, J., \& Millichap, N. (2015). The next generation digital learning environment.

Ghilay, Y. (2017). Online learning in higher education. New York, NY: Nova Science Publishers.

J. Cummins, J Brown, and D. Sayers (2007) Literacy, technology, and diversity: Teaching for success in changing times. Boston: Pearson. 
IJOTL TL, Vol. 4, No. 3, September 2019

p ISSN: 2502 2326; e ISSN: 2502 8278

Https://soloclcs.org; Email: ijolt1@gmail.com

Center of Language and Cultural Studies, Surakarta, Indonesia

Rahman, Dzul; Sunarti \& Arbain. 2019. The Effect of E-learning Based Schoology

on the Learning Outcomes in Nursing Program.

IJOTL TL (2019), 4(3): 163 172. DOI: 10.30957/ijotl-tl.v4i3.607.

J. Sánchez, O. Zegarra, (2017) "Aplicación del Programa Virtual LMS-Schoology para mejorar el Rendimiento Académico del área de Investigaciónen Estudiantes de Maestría de la Universidad Autónoma del Perú". In: IV Congreso Iberoamericano de Estilos de Aprendizaje. Concepción, Chile, pp.1-25.

K. C. Vilo, (2014) "Manual imprescindible redes sociales para la educación", Educación XXI, vol.14, no.1, pp.. 293-294.

Malikowski, S. R., Thompson, M. E. \&Theis, J. G. (2007). A model for research into course management system: Bridging technology and learning theory. Journal of Education Computing Research, 36(2), 148-173

Mulyono, H. (2016). Using quipper as an online platform for teaching and learning english as a foreign language.

Nasrullah, Rulli. (2015). Media Sosial: Perspektif Komunikasi, Budaya, dan Sosioteknologi, Bandung: Simbiosa Rekatama Media

Pilli, O. (2014). LMS Vs. SNS: Can social networking sites act as a learning management system? American International Journal of Contemporary Research, 4(5), 90-92.

Purnawarman, Pupung \& Susilawati, Susilawati \& Sundayana, Wachyu. (2016). The use of Edmodo in teaching writing in a blended learning setting. Indonesian Journal of Applied Linguistics. 5. 242. 10.17509/ijal.v5i2.1348.

Ratnasari, Desi; Arbain. The design of speaking materials for hospitality students of Trans Ocean Floating Hotel program based on competency based language teaching approach. Journal of English Language and Pedagogy, [S.1.], v.2, n. 2, p. 121-130, nov. 2019. ISSN 2579-8782. Available at: $<$ http://jurnal.ustjogja.ac.id/index.php/ELP/article/view/4878>. Date accessed: 23 dec. 2019. doi:http://dx.doi.org/10.36597/jelp.v2i2.4878.

S. Biswas (2013) "Schoology-Supported Classroom Management: A Curriculum Review". Northwest J Teach Educ, vol.11, no.2.

Schrock, Andrew. (2006). Myspace Or Ourspace: A Media System Dependency View Of Myspace, Thesis, University Of Central Florida.

Steinberg, S. \& Riehl, J. (2013). Technology lessons by age group. In J. L. Tahnk (Ed.), Teaching technology: High-tech education, safety and online learning for teachers, kids and parents (pp. 91-99). New York: Read Me.

Stošić, L. (2015). The importance of educational technology in teaching. International Journal of Cognitive Research in Science, Engineering and Education, 3(1), 111-114

Stockwell, Glenn. (2013). Technology and Motivation in English-Language Teaching and Learning. 10.1057/9781137000873 9.

Sucipto, T. L. A., Efendi, A., Hanif, H. N., \& Budiyanto, C. (2017). The Influence of Learning Management Technology to Student's Learning Outcome. IJPTE: 
IJOTL TL, Vol. 4, No. 3, September 2019

p ISSN: 2502 2326; e ISSN: 2502 8278

Https://soloclcs.org; Email: ijolt1@gmail.com

Center of Language and Cultural Studies, Surakarta, Indonesia

Rahman, Dzul; Sunarti \& Arbain. 2019. The Effect of E learning Based Schoology

on the Learning Outcomes in Nursing Program.

IJOTL TL (2019), 4(3): 163 172. DOI: 10.30957/ijotl-tl.v4i3.607.

International Journal of Pedagogy and Teacher Education, 1(1). doi: 10.20961/ijpte.v1i1.4606

Taylor, Victoria, (2013) Japan to Launch 'Fasting' Camps for Internet Addicted Students, dalam http://www.nydailynews.com/lifestyle/japan-launch-internetfastingcamps-article-1.1440483

Tugiyo Aminoto \& Hairul Pathoni. (2014). Penerapan Media E-Learning Berbasis Schoology Untuk Meningkatkan Aktivitas dan Hasil Belajar Materi Usaha dan Energi Di Kelas XI SMA N 10 Kota Jambi. Jurnal Sainmatika Vol. 8, No. 1. 2014. ISSN 1979-0910

W. J. McKeachie, and M. Svinicki, (2006) "McKeachie's teaching tips: Strategies, research, and theory for college and university teachers". Boston: HoughtonMifflin, 2006.

Wright, C. R., Lopes, V., Montgomerie, C., Reju, S., \& Schmoller, S. (2014). Selecting a learning management system: Advice from an academic perspective.

Young, Kimberly S., and de Abreu, Cristiano Nabuco. 2011. Internet Addiction- A Handbook and Guide to Evaluation and Treatment, John Wiley \& Sons Inc, Canada 